\title{
Highly-active Pd-Cu Electrocatalysts for Oxidation of Ubiquitous Oxygenated Fuels
}

Alexey Serov[a], Tristan Asset[b,c], Monica Padilla[a], Ivana Matanovic[a,g], Ulises

Martinez[a], Aaron Roy[a], Kateryna Artyushkova [a], Marian Chatenet[b,c,d], Frederic

Maillard[b,c], Domnik Bayer[e], Carsten Cremers[e], and Plamen Atanassov*[a]

Dr. P. Atanassov, Department of Chemical \& Biological Engineering and Center for MicroEngineered Materials (CMEM), The University of New Mexico, Advanced Materials Laboratory, Albuquerque, New Mexico 87131, USA. Email: plamen@unm.edu

Keywords: fuel cell $\bullet$ alcohols electrooxidation $\bullet$ alkaline $\bullet$ palladium $\bullet$ sacrificial support method $(\mathrm{SSM})$

Abstract: Nanostructured palladium-copper electrocatalysts with Pd:Cu ratios of 1:3, 1:1, and 3:1 were synthesized using a Sacrificial Support Method (SSM) in combination with the thermal reduction of metal precursors. The materials were comprehensively characterized by X-ray diffraction (XRD), X-ray Photoelectron Spectroscopy (XPS), Scanning and Transmission Electron Microscopy (SEM and TEM), surface area measurements (Brunauer-Emmett-Teller, BET) and Differential Electrochemical Mass Spectroscopy (DEMS). The SSM method enables the preparation of nano-sized unsupported $\mathrm{Pd}-\mathrm{Cu}$ catalysts with uniformly-distributed particles and high surface area, in the range of $40 \mathrm{~m}^{2} \mathrm{~g}_{\text {catalyst }}{ }^{-1}$. Their catalytic activity for the 
electrooxidation of several alcohols (methanol, ethanol, ethylene glycol and glycerol) was investigated in alkaline media. In situ Infrared Reflection Adsorption Spectroscopy (IRRAS) and Density Functional Theory (DFT) calculations were used in order to understand the mechanism of the various alcohols electrooxidation reactions.

[a] Dr. A. Serov, M. Padilla, Dr. I. Matanovic, Dr. U. Martinez, Dr. K. Artyushkova, Dr. P. Atanassov, Department of Chemical \& Biological Engineering and Center for Micro-Engineered Materials (CMEM), The University of New Mexico, Advanced Materials Laboratory, Albuquerque, New Mexico 87131, USA Email: plamen@unm.edu

[b] T. Asset, Pr. M. Chatenet, Dr. F. Maillard, Univ. Grenoble Alpes LEPMI, F-38000 Grenoble, France.

[c] T. Asset, Pr. M. Chatenet, Dr. F. Maillard, CNRS, LEPMI, F-38000 Grenoble, France.

[d] Pr. M. Chatenet, Institut Universitaire de France, Paris, France.

[e] Dr. D. Bayer, Dr. C. Cremers, Fraunhofer Institute for Chemical Technology, ICT, Pfinztal, Germany

[g] Ivana Matanovic secondary address: Theoretical Division, Los Alamos National Laboratory, Los Alamos, NM, 87545, USA

Domnik Bayer current address: BASF SE, GCN-EP, 67056 Ludwigshafen, Germany Supporting information for this article is given via a link at the end of the document.

\section{Introduction}

Direct Liquid Fed Fuel Cells (DLFFCs) recently attracted attention of many researchers around the globe due to their multiple advantages, linked to the use of liquid fuels instead of hydrogen 
gas. Among these benefits, one can cite their high volumetric and gravimetric energy densities as well as the simplicity of storage, transportation and distribution of their fuel. [1-3]

Alcohols are one example of liquid fuels that have been considered as promising for DLFFCs, since their use is compatible with broad applications, from mobile to back-up power devices. In addition, several alcohols are side-products of biomass conversion, which makes them "greener" than fuels of fossil origin, and they can be valuable alternatives to hydrogen. The existing alcohol-fed DLFFCs prototype devices operate with proton exchange membranes of the perfluorosufonic family, mainly Nafion ${ }^{\circledR}$-based polymers. At the moment, such systems have lower performance compared to hydrogen-fed PEMFCs, due to detrimental fuel cross-over, slow kinetics of alcohol electrooxidation, and low stability and durability mainly because of their poisoning by side-products or intermediates of electrooxidation. [1-3] Furthermore, platinum which is the main catalyst used in DLFFCs is an expensive and rare metal hindering the wide deployment of this fuel cell technology. Therefore, electrocatalysts materials that could substitute platinum are currently explored extensively by the scientific community.

It is well known that palladium and palladium-based nanostructured materials have wide applications in the field of electrocatalysis for the fuel cells application.[4] Those materials can be utilized in Membrane Electrode Assembly (MEA) either on the cathode $[4,5]$ or on the anode sides of DLFFC [6-12]. As stated by Antolini, the activity of Pd for alcohol oxidation is very low in acidic media but relatively high in alkaline media.[4] Additionally, the activity of Pd for alcohol oxidation can be enhanced by adding a co-catalytic element, mainly metal (either d- or pmetals), or compounds such as oxides.[4]

In that context, the present paper targets the substitution of platinum-based catalysts by cheaper materials based on palladium for the alkaline/anion exchange membrane fuel cell 
application with the utilization of several $\mathrm{C}_{1}-\mathrm{C}_{3}$ alcohols (methanol, ethanol, glycerol and ethylene glycol). This work also investigates the improvement of the activity of pure palladium by promotion effect using copper metal and oxides. The activity of unsupported palladium was compared to that of family of nanostructured Pd-Cu electrocatalysts (with the ratio between Pd and $\mathrm{Cu}: 1: 3,1: 1$ and 3:1) synthesized by the same method. The materials were prepared using the Sacrificial Support Method (SSM) [13-26], previously developed at UNM with a modification for the preparation of unsupported platinum group metals electrocatalysts. The SSM is a powerful and flexible method, which can be adopted for the synthesis of tailored high-surface area self-supported electrocatalysts and other classes of nanostructured materials. We are reporting that the above-mentioned materials can be considered as promising electrocatalysts for utilization in DLFFC anodes fed with $\mathrm{C}_{1}-\mathrm{C}_{3}$ oxygenated molecules.

\section{Experimental Section}

Catalyst preparation: high surface area silica (Cab-O-Sil ${ }^{\mathrm{TM}} \mathrm{EH}-5$, surface area: $\sim 400 \mathrm{~m}^{2} \mathrm{~g}^{-1}$ ) was firstly dispersed in water using a high energy ultrasonic probe. Appropriate amounts of $\mathrm{Pd}\left(\mathrm{NO}_{3}\right)_{2} * \mathrm{xH}_{2} \mathrm{O}$ and $\mathrm{Cu}\left(\mathrm{NO}_{3}\right)_{2} * \mathrm{xH}_{2} \mathrm{O}$ (Sigma-Aldrich) were added to the aqueous silica suspension. The overall metal loading on silica was targeted to $c a .25 \mathrm{wt} \%$ of final electrocatalyst after reduction. The silica and metal precursors' suspension was then allowed to dry on ultrasonic bath overnight. The obtained dry powder was ground in an agate mortar and pestle until a fine powder was obtained. It was then thermally reduced in $7 \% \mathrm{H}_{2}$ atmosphere (100 $\mathrm{cm}^{3} \mathrm{~min}^{-1}$ flow rate) at $T=300^{\circ} \mathrm{C}$, for $2 \mathrm{~h}$. After reduction, the catalysts were passivated in a flow of technical-grade nitrogen $\left(\sim 0.1\right.$ at. $\left.\% \mathrm{O}_{2}\right)$. The silica support was etched by means of $8 \mathrm{M} \mathrm{KOH}$ overnight and the resulting unsupported $\mathrm{Pd}_{\mathrm{x}} \mathrm{Cu}_{\mathrm{y}}$ electrocatalysts were washed with de-ionized water (DI water) until neutral $\mathrm{pH}$ was reached. The values of atomic $\mathrm{Pd}$ to $\mathrm{Cu}$ ratio were selected 
as $3: 1,1: 1$ and $1: 3$, and the corresponding electrocatalysts were nominally denoted as $\mathrm{Pd}_{3} \mathrm{Cu}$, $\mathrm{PdCu}$ and $\mathrm{PdCu}_{3}$, respectively. For comparison, unsupported palladium was also synthesized by the method described above (using the palladium nitrate only), and the catalytic activity of the $\mathrm{Pd}_{\mathrm{x}} \mathrm{Cu}_{\mathrm{y}}$ electrocatalysts was compared with that of pure $\mathrm{Pd}$.

Characterization: The electrocatalyst materials were characterized is terms of morphology, phase composition, and chemical composition using SEM (Hitachi S-5200 Nano SEM, with an accelerating voltage of $15 \mathrm{keV}$ ), TEM (JEOL 2010, with an accelerating voltage of $200 \mathrm{keV}$ ), XRD and X-Ray Energy Dispersive Spectroscopy (X-EDS). SEM and TEM provided information on the morphology of the bulk and individual particles of the electrocatalysts while X-EDS was used to estimate the composition of the samples and compare it to the target composition. X-ray diffraction was performed using a Scintag Pad V diffractometer (BraggBrentano geometry) and DataScan 4 software (from MDI, Inc.) was utilized for system automation and data collection. $\mathrm{Cu} \mathrm{K} \mathrm{K}_{\alpha}$ radiation $(40 \mathrm{kV}, 35 \mathrm{~mA})$ was used with a Bicron Scintillation detector (pyrolytic graphite curved crystal monochromator). Surface areas were also measured by nitrogen sorption (Brunauer-Emmett-Teller method) using a Micromeritics 2360 Gemini Analyzer.

In situ Infrared Reflection-Adsorption Spectroscopy (IRRAS) experiments were performed at room temperature with a Nicolet 6700 FTIR spectrometer equipped with a liquid-nitrogencooled Mercury Cadmium Telluride (MCT) detector (see Refs. [27, 28] for details of the setup). Each spectrum was obtained from 128 co-added spectra, acquired at a resolution of $8 \mathrm{~cm}^{-1}$, using non-polarized light, during a slow-scan linear sweep voltammetry (scan rate at $v=0.001 \mathrm{~V} \mathrm{sec}^{-}$ $\left.{ }^{1}\right)$. The data was presented in terms of absorbance of the spectra, defined as $A=-\log \left(R / R_{0}\right)$, where $R$ and $R_{0}$ represent reflected IR intensities corresponding to the sample and reference 
single beam spectrum, respectively. In this configuration, a positive band in the spectrum signs the appearance of chemical species, while a negative band indicates a decrease in the concentration of a species (or disappearance), as compared to the reference spectrum. The reference spectrum was collected at $E=-1.10 \mathrm{~V} v$ s. $\mathrm{Ag} / \mathrm{AgCl} / \mathrm{Cl}_{\text {sat }}^{-}$. In all cases, the potentials have been corrected to the reversible hydrogen electrode (RHE) scale. The working electrode was prepared by depositing a thin layer of ink of the electrocatalyst onto a polished glassy carbon electrode with a diameter of $5 \mathrm{~mm}$. The IR window was a $\mathrm{ZnSe}$ hemisphere, and the working electrode was gently pressed against this window, creating a thin solution layer with a thickness of a few micrometers. The incident angle of the IR radiation passing through the $\mathrm{ZnSe}$ window was $36^{\circ}$. During the whole experiment, argon was purged into the electrolyte, and the spectrometer and chamber were purged by dry air, reducing the spectral interference from ambient $\mathrm{CO}_{2}$ and water vapor.

XPS spectra were acquired on a Kratos Axis DLD Ultra X-ray photoelectron spectrometer using a monochromatic $\mathrm{Al} \mathrm{Ka}$ source operating at $150 \mathrm{~W}$ with no charge compensation. The base pressure was about $10^{-10}$ Torr, and operating pressure was $10^{-9}$ Torr. Survey and high-resolution spectra were acquired at pass energies of 80 and $20 \mathrm{eV}$ respectively. Data analysis and quantification were performed using CasaXPS software. A linear background subtraction was used for quantification of $\mathrm{C} 1 \mathrm{~s}$ and O1s spectra while a Shirley background was applied to $\mathrm{Cu} 2 \mathrm{p}$ and Pd3d spectra. Sensitivity factors provided by the manufacturer were utilized. A $70 \%$ Gaussian/30\%Lorentzian line shape was used in the curve-fit of N1s.

The electrochemical analysis of the synthesized material was performed by rotating disk electrode (RRDE) experiments using the Pine Instrument Company electrochemical analysis system. The revolution rate was set at $\Omega=1600 \mathrm{RPM}$, and the scan rate at $v=0.020 \mathrm{~V} \mathrm{sec}^{-1}$. The 
electrolyte was $1 \mathrm{M} \mathrm{KOH}$ containing $1 \mathrm{M}$ of the studied alcohols $(\mathrm{MeOH}$ and $\mathrm{EtOH})$ or $0.1 \mathrm{M}$ in the case of EG and glycerol saturated in $\mathrm{N}_{2}$ at room temperature. A platinum wire counterelectrode and $\mathrm{Hg} / \mathrm{HgO}$ reference electrode were used, but the potentials were corrected for the RHE scale. The inks for working electrodes were prepared by mixing $5 \mathrm{mg}$ of the desired $\operatorname{Pd}_{\mathrm{x}} \mathrm{Cu}_{\mathrm{y}}$ electrocatalyst with $925 \mu \mathrm{L}$ of a water and isopropyl alcohol (4:1) mixture, and $75 \mu \mathrm{L}$ of Nafion ${ }^{\circledR}$ (0.5 wt. \%, DuPont). The mixture was mixed and dispersed by sonication, before $10 \mu \mathrm{L}$ was applied onto a glassy carbon disk (surface area of $0.2472 \mathrm{~cm}^{2}$ ). The loading of catalyst on the electrode was in all cases $0.2 \mathrm{mg}_{\text {catalyst }} \mathrm{cm}^{-2}$.

DEMS measurements were performed in a flow thorough DEMS cell set-up. In this cell the working electrode consists of a thin micro-porous PTFE membrane provided by W.C. Gore. The membrane is sputter coated with a thin layer of gold so that most of the pores remain open. The gold is used as electron conductor for the catalyst layer which is applied by spray coating. The ink for the spray coating consist of $100 \mathrm{mg}$ of catalyst dispersed in $3 \mathrm{~g}$ of ethanol to which 100 $\mathrm{mg}$ of Teflon ${ }^{\circledR}$ dispersion (DuPont) $5 \mathrm{wt} \%$ in water were added. As counter electrode, a platinum mesh placed in a separate compartment downstream of the working electrode compartment is used. As reference electrode, a $\mathrm{Hg} / \mathrm{HgO}$ electrode is used, which is placed in a third compartment connected to the working electrode compartment by capillary tubing through which a trickling stream of pure electrolyte is maintained. Mass spectrometric voltammograms (MSCVs) are recorded using a Gamry Reference 3000 potentiostat which receives the signals from the Balzer QMS 200 mass spectrometer as an additional analog input.

\section{Results and Discussion}

The phase composition of the synthesized $\mathrm{Pd}_{\mathrm{x}} \mathrm{Cu}_{\mathrm{y}}$ materials was obtained from X-ray diffraction (XRD, Figure 1). All the copper-containing samples consist of two palladium-copper 
phases: a face-centered cubic (FCC) solid solution and the primitive cubic phase $\beta$-PdCu. Additional phases, $\mathrm{Cu}_{2} \mathrm{O}$ and $\mathrm{CuO}$, were detected in samples with increased amounts of $\mathrm{Cu}$ $\left(\mathrm{PdCu}\right.$ and $\left.\mathrm{PdCu}_{3}\right)$. The total mass fraction of $\mathrm{Cu}$ oxides was calculated by $\mathrm{XRD}$ pattern refinement and was found to be $30 \mathrm{wt} . \%$ and $57 \mathrm{wt} \% \%$ for $\mathrm{PdCu}$ and $\mathrm{PdCu}_{3}$, respectively. In the case of the $\mathrm{PdCu}_{3}$ catalyst (Figure 1 (c)), equal amounts of the FCC and primitive cubic phase were observed with a mass fraction of 21 wt.\%. However, increasing the concentration of Pd resulted in an increased amount of the FCC solid solution, becoming 61 wt.\% and 97 wt.\% for the $\mathrm{PdCu}$ and $\mathrm{Pd}_{3} \mathrm{Cu}$ catalysts, respectively. Additionally, the lattice parameter $(a)$ of the FCC solid solution phase was found to increase by ca. $1.0 \%$ at each incremental increase in $\mathrm{Pd}$ content: $a=3.7973,3.8363$ and $3.8782 \AA$ for $\mathrm{PdCu}_{3}, \mathrm{PdCu}$ and $\mathrm{Pd}_{3} \mathrm{Cu}$, respectively. This result is consistent with the gradual enrichment of the solid solution phase with palladium. The average size of crystallite domains was calculated using Scherrer equation for the Pd-Cu phases. For the FCC phase, the average domain sizes for the $\mathrm{PdCu}_{3}, \mathrm{PdCu}$ and $\mathrm{Pd}_{3} \mathrm{Cu}$ catalysts were of $d_{\mathrm{FCC}}=7$, 6 and $10 \mathrm{~nm}$, respectively. For the primitive cubic phase, the average domain sizes were also roughly similar: $d_{\mathrm{C}}=21,20$ and $18 \mathrm{~nm}$ for the $\mathrm{PdCu}_{3}, \mathrm{PdCu}$ and $\mathrm{Pd}_{3} \mathrm{Cu}$ catalysts, respectively. 


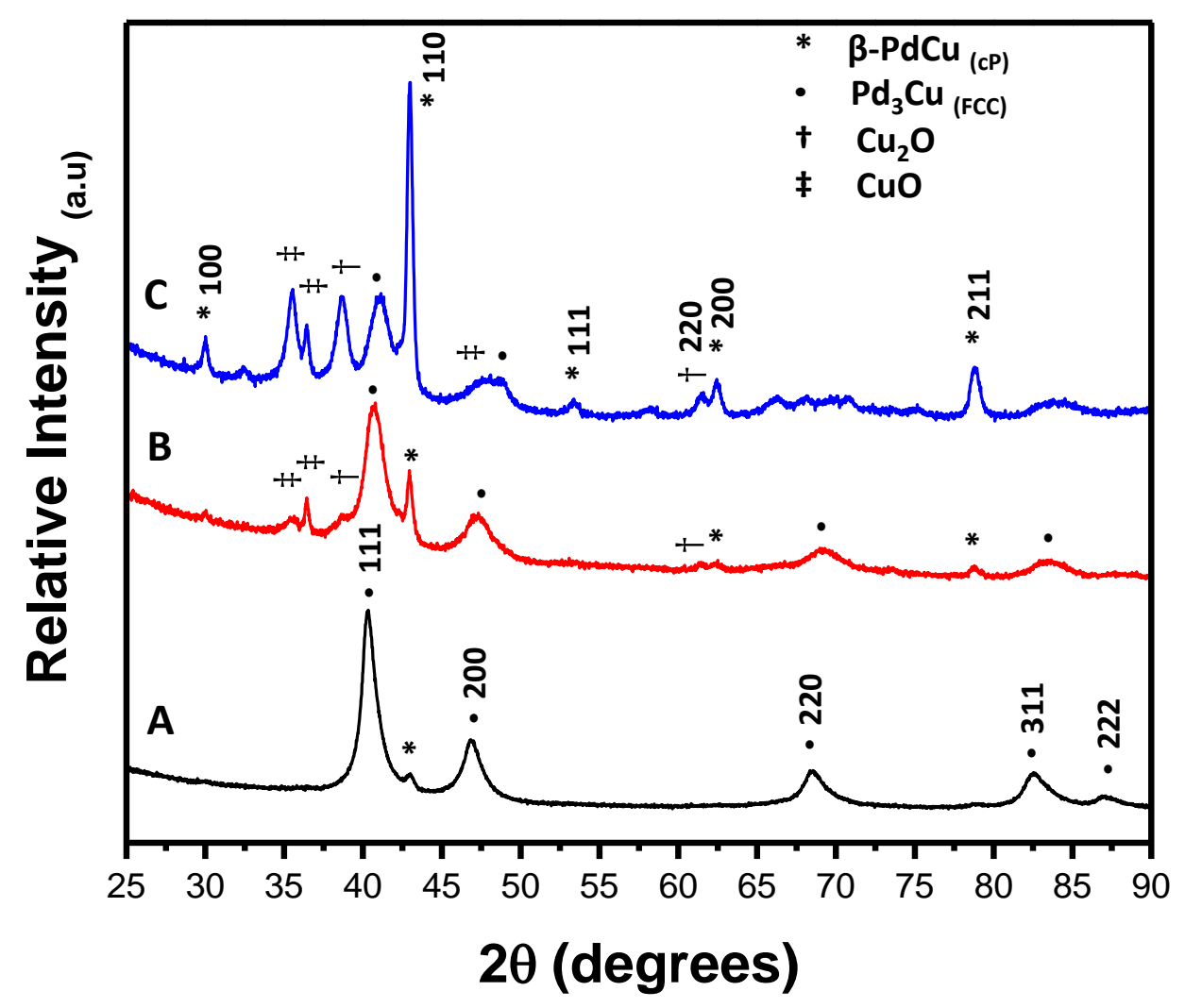

Figure 1. $\mathrm{XRD}$ data for $\mathrm{Pd}-\mathrm{Cu}$ catalysts: A) $\left.\mathrm{Pd}_{3} \mathrm{Cu}, \mathrm{B}\right) \mathrm{PdCu}$, and $\left.\mathrm{C}\right) \mathrm{PdCu}_{3}$ prepared by Sacrificial Support Method.

The morphological analysis of the $\mathrm{Pd}_{\mathrm{x}} \mathrm{Cu}_{\mathrm{y}}$ catalysts was performed by SEM imaging. Figure 2 (a-c) demonstrates that all materials have similar 3-D structures; the voids between the agglomerated particles resulted from the removal of the sacrificial support particles ( $\sim 30 \mathrm{~nm}$ for fumed silica). The (less-abundant) presence of larger voids in the material originates from the existence of $\mathrm{SiO}_{2}$ agglomerates within the colloidal silica, with a size of $c a .100 \mathrm{~nm}$. Independent on overall composition, the prepared $\mathrm{Pd}_{\mathrm{x}} \mathrm{Cu}_{\mathrm{y}}$ catalysts displayed BET surface areas of $c a .40 \mathrm{~m}^{2}$ $\mathrm{g}_{\text {catalyst }}{ }^{-1}$, which is noticeably large for unsupported catalysts. The TEM micrographs of palladium-copper materials (Figure 3 (d-f)) demonstrate the fine distribution of the $\mathrm{PdCu}$ and $\mathrm{Pd}_{3} \mathrm{Cu}$ nanoparticles in the form of open agglomerates; these agglomerates do not display signs of excessive coalescence (in other words, the crystallites touch each-other but remain separated 
in terms of crystalline lattice, which is in agreement with the small sizes of the crystallite domains $d_{\mathrm{C}}$ and $d_{\mathrm{FCC}}$ obtained by XRD). The picture drastically changes in the case of $\mathrm{PdCu}_{3}$ : the agglomerated nanoparticles coalesce into larger features, which is likely due to the large copper concentration and $\mathrm{Cu}_{2} \mathrm{O}$ oxide detected in XRD (indeed, the values of $d_{\mathrm{C}}$ and $d_{\mathrm{FCC}}$ are not significantly larger than for the $\mathrm{PdCu}$ and $\mathrm{Pd}_{3} \mathrm{Cu}$ samples). For all materials the morphology of the $\mathrm{Pd}_{\mathrm{x}} \mathrm{Cu}_{\mathrm{y}}$ electrocatalysts is characterized by well-developed 3D structure, with large BET surface area and fine particle size distribution, thereby demonstrating the benefits of the Sacrificial Support Method.

A)
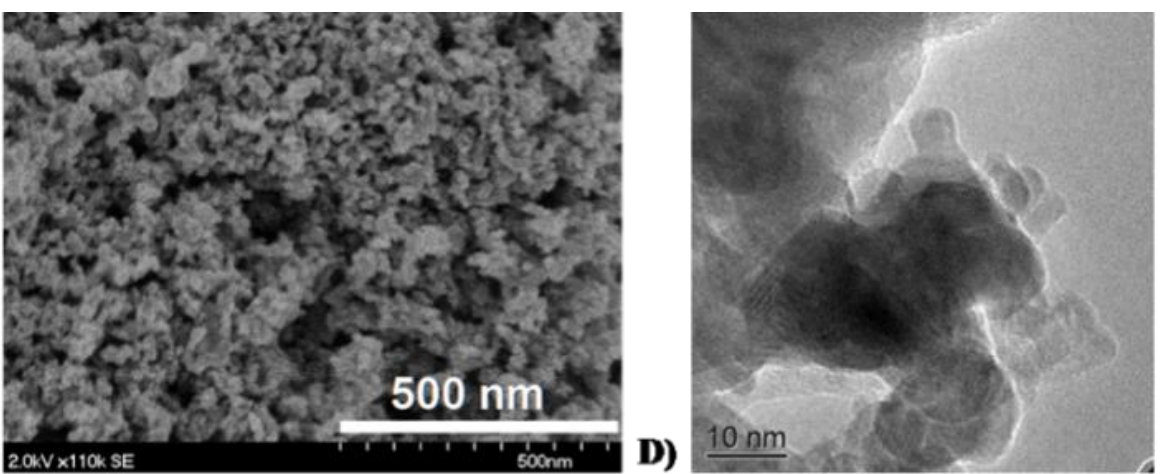

B)
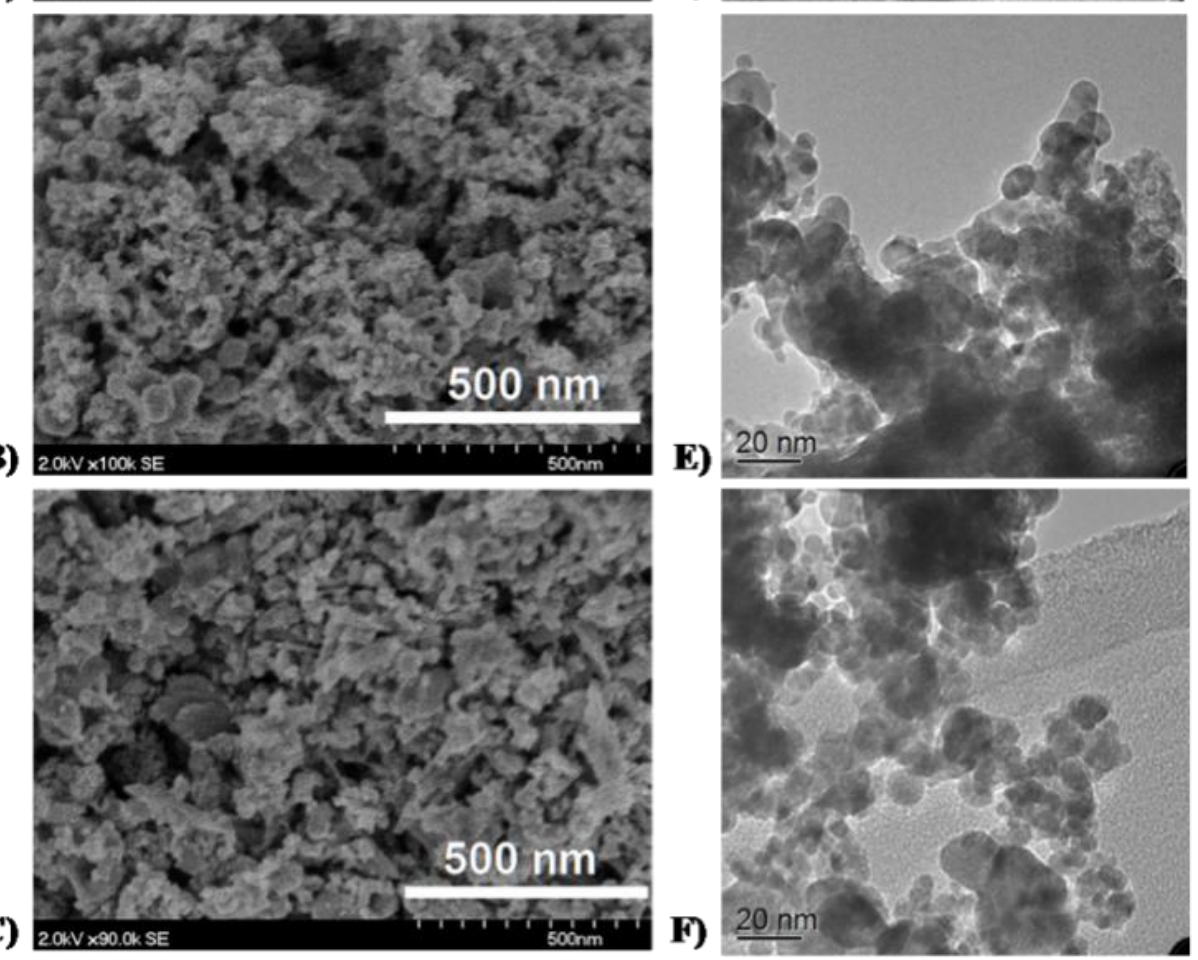
Figure 2. $\mathrm{SEM}(\mathrm{A}-\mathrm{C})$ and $\mathrm{TEM}(\mathrm{D}-\mathrm{F})$ images for $\mathrm{Pd}_{\mathrm{x}} \mathrm{Cu}_{\mathrm{y}}$ catalysts prepared by thermal reduction of precursors. A, D: $\mathrm{PdCu}_{3}, \mathrm{~B}, \mathrm{E}: \mathrm{PdCu}$ and $\mathrm{C}, \mathrm{F}: \mathrm{Pd}_{3} \mathrm{Cu}$.

High-resolution X-ray photoelectron spectroscopy was utilized to study the surface chemical composition of $\mathrm{Pd}_{\mathrm{x}} \mathrm{Cu}_{\mathrm{y}}$ electrocatalysts. The $\mathrm{Pd} / \mathrm{Cu}$ ratios obtained for electrocatalysts were 1:3, 0.75:1, and 1.53:1 for $\mathrm{PdCu}_{3}, \mathrm{PdCu}$ and $\mathrm{Pd}_{3} \mathrm{Cu}$, respectively. Surface segregation of $\mathrm{Cu}$ was observed, particularly for 1:1 and 3:1 samples. It should be noticed that sampling depth for $\mathrm{Cu}$ atoms is twice smaller than that for $\mathrm{Pd}$, so particles with $\mathrm{Cu}$ shell around the $\mathrm{Pd}-\mathrm{Cu}$ intermixed alloy, have an enrichment of $\mathrm{Cu}$ at the surface.

In order to obtain the surface composition of copper oxide a high-resolution $\mathrm{Cu} 2 \mathrm{p}$ spectrum was fitted with 4 peaks which were originated from: $\mathrm{PdCu}$ alloy phase at $931.6 \mathrm{eV} ; \mathrm{Cu}_{2} \mathrm{O}$ at $933.1 \mathrm{eV} ; \mathrm{CuO}$ at $934.4 \mathrm{eV}$; and copper hydroxides at $936.1 \mathrm{eV}$. The substantially pronounced satellite peak which is indicative of copper oxide presence was also detected at higher binding energy. For $\mathrm{Cu}$-rich sample $\mathrm{PdCu}_{3}$, a large amount of higher binding energy (BE) peak from the copper oxides was observed with a palladium-copper phase peak being smallest (11.2 relative percent of the total copper presented in the samples). It was shown that for the samples with the highest nominal concertation of palladium in the materials, i.e. $\mathrm{PdCu}$ and $\mathrm{Pd}_{3} \mathrm{Cu}$, the relative intensity of palladium-copper phase peak increased up to 26 at.\% for $\mathrm{Pd}_{3} \mathrm{Cu}$, which is direct indication of higher concentration of palladium atoms in the surface of electrocatalysts.

Further analysis included the fitting of high-resolution $\mathrm{Pd} 3 \mathrm{~d}$ spectrum with 4 peaks that are coming from $\mathrm{PdCu}$ phase at 335.1-335.9 eV, $\mathrm{PdO}$ at $336.9 \mathrm{eV}$ and $\mathrm{PdO}_{2}$ at $338.1 \mathrm{eV}$. It was observed that the increase of $\mathrm{Pd}$ to $\mathrm{Cu}$ ratio in the electrocatalyst resulted in significant increase of the peak $335.1 \mathrm{eV}$ intensity from $25 \%$ to $43 \%$, while the peak at $335.9 \mathrm{eV}$ stays the same. This observation was in good agreement with two categories of palladium-copper phase 
observed in XRD data (FCC and primitive cubic $\mathrm{PdCu}$ ), so peak at $335.1 \mathrm{eV}$ may be assigned to FCC while peak at 335.9 originates from primitive cubic palladium-copper phases.
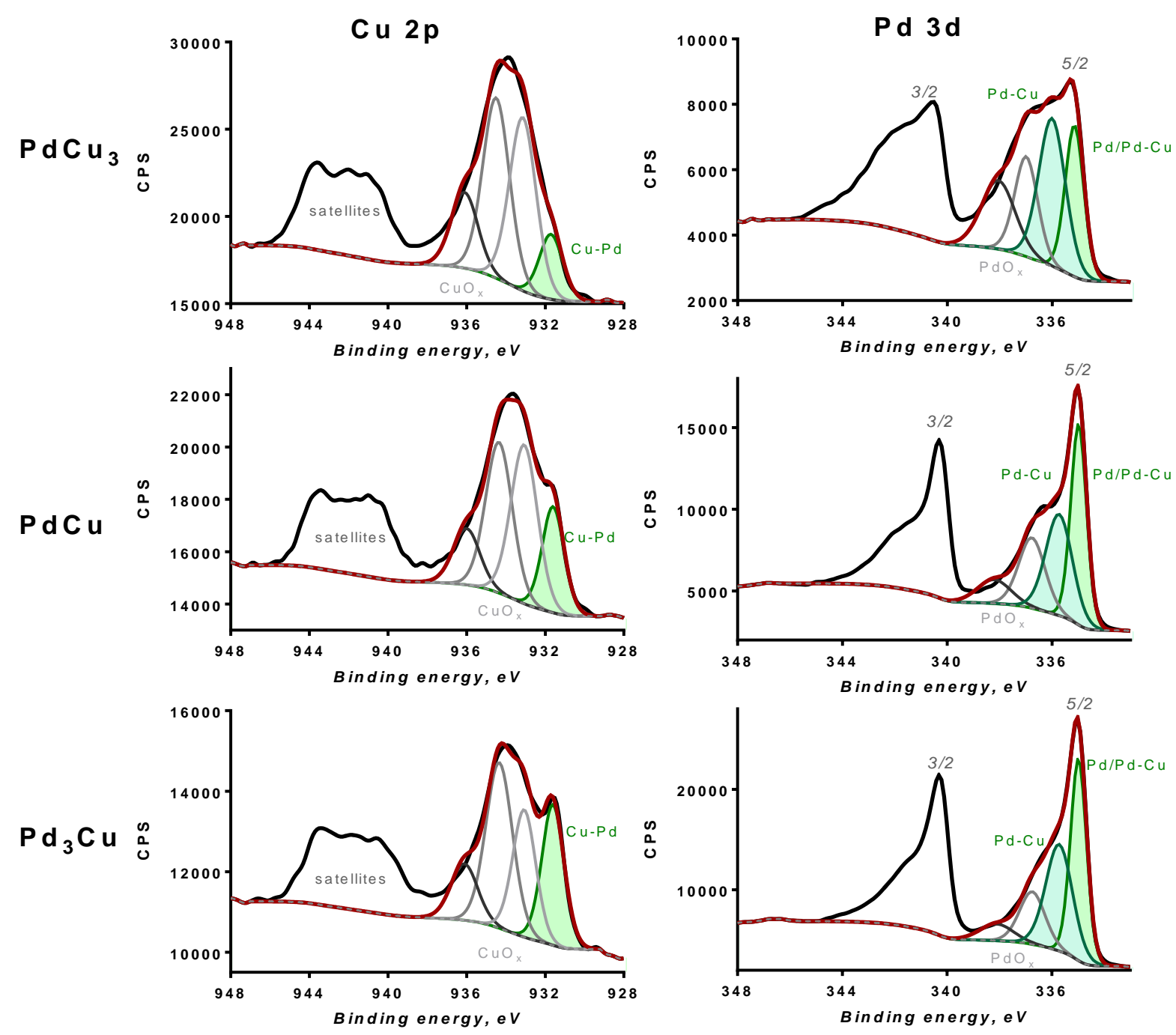

Figure 3. High resolution spectra of $\mathrm{PdCu}_{3}, \mathrm{PdCu}$ and $\mathrm{Pd}_{3} \mathrm{Cu}$ electrocatalyst.

The electrochemical data for oxidation of various light alcohols on the $\mathrm{Pd}_{\mathrm{x}} \mathrm{Cu}_{\mathrm{y}}$ electrocatalysts is summarized in Figure 4, Figure S1 and Table 1. Mass current densities were normalized to the 
mass of palladium, the most expensive element while kinetic limitations and onset of alcohol oxidation were evaluated using standard electrochemical criteria of current density. To allow for alcohol oxidation currents being registered at lower potentials than the onset itself, the onset potentials were defined as the value where the current density is equal to $5 \%$ of the peak current density, enabling the study of the influence of kinetic and Tafel slopes limitations at these potentials. The Tafel slopes $(b)$ values were therefore given in a dual manner in Table 1: the "below onset potentials" Tafel slopes and "above onset potentials" Tafel slopes. In the case of some catalyst/alcohol combinations, further calculation of a relevant Tafel slope was impossible (gray numbers in the Table 1). In all synthesized $\mathrm{Pd}-\mathrm{Cu}$ catalysts, the addition of copper improves the electrocatalytic activity of $\mathrm{Pd}-\mathrm{Cu}$ materials in comparison with pure metallic palladium. This is confirmed for all $\mathrm{PdCu}$ and $\mathrm{Pd}_{3} \mathrm{Cu}$ catalysts and all four fuels. For the $\mathrm{PdCu}_{3}$ on the other hand, the improvement was observed in the case of EG. As can be seen from Figure $3 \mathrm{~A}, \mathrm{Pd}_{3} \mathrm{Cu}$ was found to be the most active among the studied electrocatalysts towards the oxidation of methanol, followed by $\mathrm{Pd}$ and $\mathrm{PdCu}$ with the observed currents for $\mathrm{Pd}_{3} \mathrm{Cu}$ and $\mathrm{Pd}$

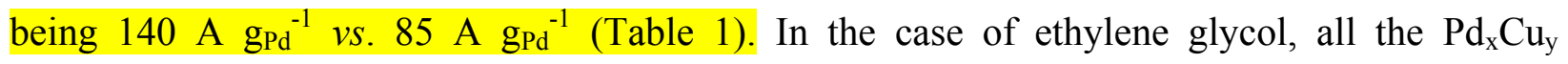
electrocatalysts exhibit increased performance $v s$. pure Pd. The electrocatalyst with the largest

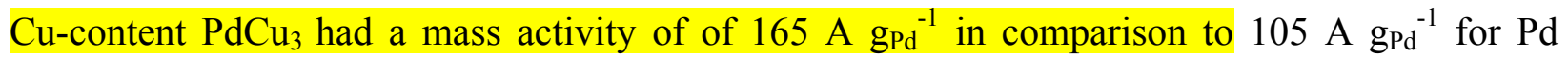
(presented at $0.75 \mathrm{~V} v s$. RHE (Figure 4C and Table 1). Such behavior can be explained by the synergy of the catalytic contribution of $\mathrm{Cu}_{2} \mathrm{O}$ for ethylene glycol oxidation and intrinsic activity of the $\mathrm{Pd}_{\mathrm{x}} \mathrm{Cu}_{\mathrm{y}}$ phases. 

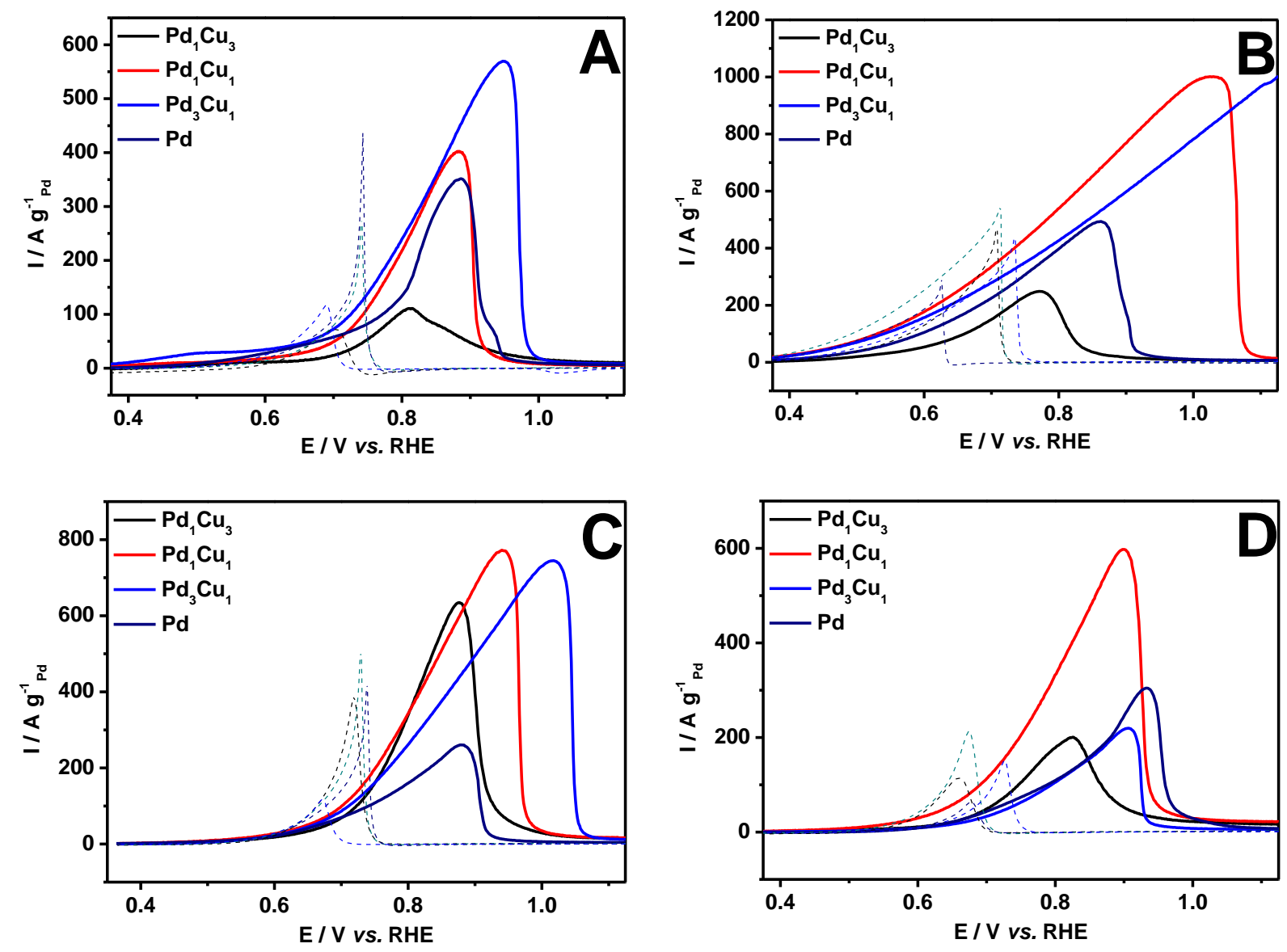

Figure 4. Cyclic voltammograms of alcohols electrooxidation by $\mathrm{Pd}_{\mathrm{x}} \mathrm{Cu}_{\mathrm{y}}$ catalysts: $\left.\mathrm{A}\right) \mathrm{MeOH}$, B) $\mathrm{EtOH}, \mathrm{C}$ ) ethylene glycol and D) glycerol. $\mathrm{PdCu}_{3}$ (black), $\mathrm{PdCu}$ (red), $\mathrm{Pd}_{3} \mathrm{Cu}$ (blue) and $\mathrm{Pd}$ (navy). Conditions: $1 \mathrm{M} \mathrm{KOH}+1 \mathrm{M} \mathrm{MeOH} / \mathrm{EtOH}(0.1 \mathrm{M} \mathrm{EG} /$ glycerol), catalyst loading $200 \mu \mathrm{g} \mathrm{cm}^{-2}, \Omega=1600$ revolutions per minute, $v=0.020 \mathrm{~V} \mathrm{~s}^{-1}$. Forward scan: full lines, backward scan: dotted lines.

The contribution of copper and copper oxides to the electrooxidation of alcohols in alkaline media, especially in the rate determining step, may occur by three different mechanisms: electronic [29-32], steric [33-35] and bi-functional effect [36-40]. In general, electronic effect occurs in the case of strong influence of add-atom on the electronic structure of main catalytic element; steric effect happens when add-atoms embed in the surface lattice of a catalyst in such a way that some active sites lose accessibility of intermediate products; and the bi-functional mechanism occurs in the case in which add-atom is as catalytically active towards the same type 
of reactions as a main active atomic site. Copper itself is not catalytically active in reactions of electrooxidation of oxygenated molecules, however, $\mathrm{Cu}, \mathrm{Cu}_{2} \mathrm{O}$ and $\mathrm{CuO}$ are well-known oxophilic element and compounds. Recently, an intrinsic effect of the alloying of the primary catalyst with a second metal resulted in a modification of the electronic structure leading to a higher catalytic performance. Oxophilic metals, such as $\mathrm{Ru}, \mathrm{Sn}$, and $\mathrm{Ni}$, have shown to improve the catalytic performance of Pt and Pd catalysts for alcohol electrooxidation [41-45]. Taking into account high oxophilicity of copper and copper oxides, the adsorption of hydroxyls will be preferable in comparison to the noble surface of palladium. Ethylene glycol and glycerol may adsorb on the catalytic surface via more than one $\mathrm{R}-\mathrm{OH}$ groups, and the rate of oxidation of those molecules will be directly dependent on the availability of hydroxyls in the vicinity of adsorbed $-\mathrm{COH}$ groups. Therefore, having copper and copper oxide populated with $-\mathrm{OH}$ groups will facilitate two step electrooxidation mechanism: (a) adsorption of EG and glycerol on the catalyst surface and (b) desorption of oxidized acyls [46].

Further electrochemical performance analysis revealed that the Tafel slope of $150 \mathrm{mV} \mathrm{dec}{ }^{-1}$ was observed in the case of $\mathrm{PdCu}_{3}$, compared to $205 \mathrm{mV} \cdot \mathrm{dec}^{-1}$ slope for Pd, followed by $200 \mathrm{mV}$ $\mathrm{dec}^{-1}$ slope for $\mathrm{PdCu}$ and $\mathrm{PdCu}_{3}$. It, therefore, appears that the catalytic improvement is induced by copper or its oxides/hydroxides as well as by the FCC solid solution (below $0.6 \mathrm{~V} v s$. RHE). The activity at potentials above $0.6 \mathrm{~V} v s$. RHE revealed that $\mathrm{PdCu}_{3}$ is characterized by the highest kinetics (Tafel slope of $140 \mathrm{mV} \mathrm{dec}{ }^{-1}$ ), followed by $\mathrm{PdCu}$ and $\mathrm{Pd}_{3} \mathrm{Cu}$, with Tafel slopes of 170 and $175 \mathrm{mV} \mathrm{dec}^{-1}$, respectively. Such trend correlates with the increase of FCC PdCu solid solution content from $\mathrm{PdCu}_{3}$ to $\mathrm{Pd}_{3} \mathrm{Cu}$ and the amounts of $\mathrm{Cu}_{2} \mathrm{O}-30$ wt.\% in $\mathrm{PdCu}$ and 57 wt.\% in $\mathrm{PdCu}_{3}$. $\mathrm{PdCu}$ outperforms all the other electrocatalysts for the oxidation of glycerol (Figure 4D), whereas similar performances were observed for the EOR, i.e. after normalization 
by the catalyst total mass (Figure S1 B). Finally, it is should be noted, that despite the fact that adding copper strongly affects the direct scan (Figure 4), it does not significantly modify the voltamperometric features of the reverse scan reactivation peak, which is attributed to the reduction of the palladium surface oxides [3]. This peak develops at similar potential values ( $c a$. $0.75 \mathrm{~V} v s$. RHE) for nearly all catalysts and fuels, suggesting that copper adjunction to palladium does not have any significant influence on the desorption potential of $\mathrm{OH}_{\text {ads }}$ from $\mathrm{Pd}$ atoms (which was confirmed by further DFT calculation, see below).

Table 1. Alcohol oxidation (MOR, EOR, EGOR and GOR) parameters for $\mathrm{Pd}_{\mathrm{x}} \mathrm{Cu}_{\mathrm{y}}$ and $\mathrm{Pd}$ catalysts. Tafel slopes (b) observed below the onset potential are given on the column left side, whereas the one observed above this potential are given right side. The absence of relevant Tafel slope was indicated by a grey marker in the table.

\begin{tabular}{|c|c|c|c|c|c|c|c|c|}
\hline & & $\mathrm{Pd}$ & \multirow{2}{*}{\multicolumn{2}{|c|}{$\mathrm{Pd}_{3} \mathrm{Cu}$}} & \multicolumn{2}{|c|}{$\mathrm{PdCu}$} & \multicolumn{2}{|c|}{$\mathrm{PdCu}_{3}$} \\
\hline \multirow{3}{*}{ Methanol } & 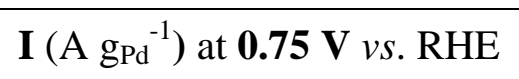 & 85 & & & \multicolumn{2}{|c|}{110} & \multicolumn{2}{|c|}{55} \\
\hline & Onset (V vs. RHE) & 0.55 & \multicolumn{2}{|c|}{0.5} & \multicolumn{2}{|c|}{0.61} & \multicolumn{2}{|c|}{0.63} \\
\hline & Tafel Slope $\left(\mathrm{mV} \operatorname{dec}^{-1}\right)$ & & & & & & & \\
\hline \multirow{3}{*}{ Ethanol } & $\mathrm{I}\left(\mathrm{A}_{\mathrm{gd}_{\mathrm{Pd}}}{ }^{-1}\right)$ at $0.75 \mathrm{~V}$ vs. RHE & 305 & \multicolumn{2}{|c|}{350} & \multicolumn{2}{|c|}{435} & \multicolumn{2}{|c|}{230} \\
\hline & Onset (V vs. RHE) & 0.46 & \multicolumn{2}{|c|}{0.46} & \multicolumn{2}{|c|}{0.46} & \multicolumn{2}{|c|}{0.46} \\
\hline & Tafel Slope $\left(\mathrm{mV} \operatorname{dec}^{-1}\right)$ & 180 & 195 & & 210 & & 160 & 230 \\
\hline \multirow{3}{*}{$\begin{array}{c}\text { Ethylene } \\
\text { Glycol }\end{array}$} & $\mathrm{I}\left(\mathrm{A} \mathrm{g}_{\mathrm{Pd}}{ }^{-1}\right)$ at $0.75 \mathrm{~V} v s$. RHE & 105 & \multicolumn{2}{|c|}{160} & \multicolumn{2}{|c|}{200} & \multicolumn{2}{|c|}{165} \\
\hline & Onset (V vs. RHE) & 0.63 & \multicolumn{2}{|c|}{0.63} & \multicolumn{2}{|c|}{0.63} & \multicolumn{2}{|c|}{0.63} \\
\hline & Tafel Slope $\left(\mathrm{mV} \mathrm{dec}{ }^{-1}\right)$ & 205 & 150 & 175 & 200 & 170 & 200 & 140 \\
\hline \multirow{3}{*}{ Glycerol } & $\mathrm{I}\left({\mathrm{A} \mathrm{g}_{\mathrm{Pd}}}^{-1}\right)$ at. $0.75 \mathrm{~V} v s$. RHE & 75 & \multicolumn{2}{|c|}{65} & \multicolumn{2}{|c|}{205} & \multicolumn{2}{|c|}{105} \\
\hline & Onset $(\mathrm{V} v s . \mathrm{RHE})$ & 0.63 & \multicolumn{2}{|c|}{0.62} & \multicolumn{2}{|c|}{0.6} & \multicolumn{2}{|c|}{0.59} \\
\hline & Tafel Slope $\left(\mathrm{mV} \mathrm{dec}{ }^{-1}\right)$ & & \multicolumn{2}{|c|}{185} & \multicolumn{2}{|c|}{185} & & 140 \\
\hline
\end{tabular}

$\mathrm{PdCu}_{3}$, which contains a significant proportion of copper-oxide phases $(57 \mathrm{wt} \%$, including $\mathrm{Cu}_{2} \mathrm{O}$ ), shows an extremely low performance for methanol and ethanol oxidation, but a higher performance than $\mathrm{Pd}_{3} \mathrm{Cu}$ and $\mathrm{Pd}$ electrocatalysts for the oxidation of ethylene glycol and glycerol 
(Table 1). Such an effect is based on promotion mechanism of oxides conjugated with decreased electrical conductivity of cuprous oxide. Much larger peak currents are observed for $\mathrm{Pd}_{3} \mathrm{Cu}$ and Pd for the EG oxidation reaction (EGOR) and the EOR, whereas the Tafel slopes (for EOR) and onset potentials are similar, which is an indication of similar specific activity of the active sites. This shows that the palladium-copper solid solution must have a higher density of active sites compared to metallic palladium, which is in perfect agreement with a surface chemical composition obtained by XPS. On the other hand, the larger MOR currents measured at low potential values $(0.4<E<0.6 \mathrm{~V} v s$. $\mathrm{RHE})$ on $\mathrm{Pd}_{\mathrm{x}} \mathrm{Cu}_{\mathrm{y}} v s$. $\mathrm{Pd}$ (especially for the $\mathrm{Pd}_{3} \mathrm{Cu}$ catalyst, see Figure 4A) show that the PdCu solid solution exhibits improved MOR kinetics as compared to palladium, which also implies that the above mentioned $\mathrm{PdCu}$ solid solution participates in full electrooxidation of methanol. The electrochemical processes in $\mathrm{GOR}$ at $\mathrm{Pd}_{3} \mathrm{Cu}, \mathrm{PdCu}$ and $\mathrm{PdCu}_{3}$ have characteristics of a kinetic rate determining step (associated with adsorption of alcohol molecule), which was shown by the linear behavior of their activity between 0.4 and 0.8 V vs. RHE: $b=140-185 \mathrm{mV} \mathrm{dec} c^{-1}$. This result indicates that the $\mathrm{Pd}_{\mathrm{x}} \mathrm{Cu}_{\mathrm{y}}$ solid solution has no influence on the intrinsic reaction kinetics in the case of GOR. The slight improvement in onset potentials (Table 1) observed for the oxidation of methanol and glycerol (for at least one composition), implies that the addition of copper to palladium leads to modifications in chemisorption properties, which is usually associated with adsorption of oxygenated molecules on the surface of electrocatalysts. Different copper oxides may play a dual role in the electrocatalytic activity of the synthetized palladium-based catalysts. Previously in the literature $\mathrm{Xu}$ et al. have demonstrated the promotion effect of $\mathrm{CeO}_{2}, \mathrm{NiO}, \mathrm{Co}_{3} \mathrm{O}_{4}$, and $\mathrm{Mn}_{3} \mathrm{O}_{4}$ on palladium electrocatalysts with clear improvement of the electrooxidation performance for a number of different alcohols $[47,48]$. Further analysis of the published data revealed that both $\mathrm{CuO}$ and 
$\mathrm{Cu}_{2} \mathrm{O}$ compounds possess intrinsic electrocatalytic activity in the reaction of electrooxidation of oxygenated species such as glucose and sucrose [49-50]. It was also reported that addition of $\mathrm{CuO}$ to the platinum catalysts increases the overall activity in the reactions of methanol electrooxidation [51]. The promotion effect is explained by the increased surface coverage of the catalytic materials with $\mathrm{OH}^{-}$groups which participated in the reaction. On the other hand, it should be taken into consideration that $\mathrm{Cu}_{2} \mathrm{O}$ and $\mathrm{CuO}$ are poor electrical conductive materials, and by increasing their concentration the overall conductivity will be decreased. In the case of electrocatalysis this will lead to the decrease in measured current densities. In addition, copper oxides may influence mechanistic pathway of alcohols electrooxidation, which can be cocatalyzed by $\mathrm{Cu}_{2} \mathrm{O}$ and $\mathrm{CuO}$. As it was shown in Ref. [52] there is an optimal ratio between main catalyst (platinum) and oxide co-catalyst $(\mathrm{CuO})$ at which the synergistic effect occurs. Based on the XRD results described in the present article optimal concentration of oxides should be at the level of $30 \mathrm{wt} . \%$ for the majority of studied fuels (MOR, EOR, EGOR and GOR). The detailed study of the $\mathrm{Cu}_{2} \mathrm{O} / \mathrm{CuO}$ hybrids with palladium should be performed and presented in the standalone article.

Density Functional Theory (DFT) was used to gain better insight into the system at the atomistic level. The DFT calculations performed at present study were based on the PerdewBurke-Ernzerhof (PBE) functional [53, 54], and specifically aimed to explore the adsorption of ethanol, methanol, ethylene glycol, glycerol, and $\mathrm{OH}$ species on $\mathrm{Pd}(111)$ and $\mathrm{Pd}_{3} \mathrm{Cu}(111)$ surfaces. Figure 5 demonstrates that all alcohols interact very weakly with both selected surfaces, however slightly with higher affinity to the $\mathrm{Pd}_{3} \mathrm{Cu}(111)$ compared the $\mathrm{Pd}(111)$ surface in the case of ethanol, ethylene glycol, and glycerol. 


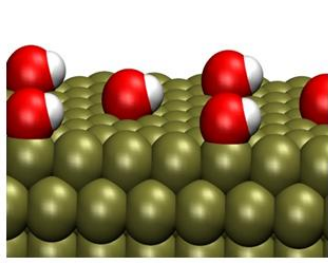

$\Delta E_{\mathrm{ad}}=-2.32 \mathrm{eV}$

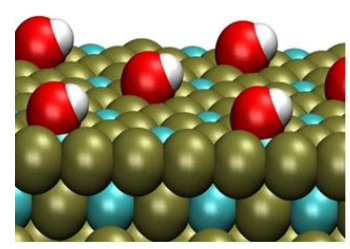

$\Delta E_{\mathrm{ad}}=-2.42 \mathrm{eV}$

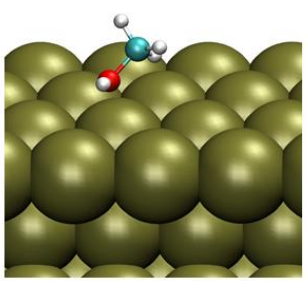

$\Delta E_{\mathrm{ad}}=-0.22 \mathrm{eV}$

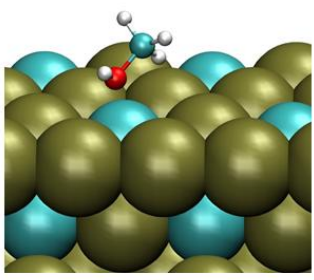

$\Delta E_{\mathrm{ad}}=-0.21 \mathrm{eV}$

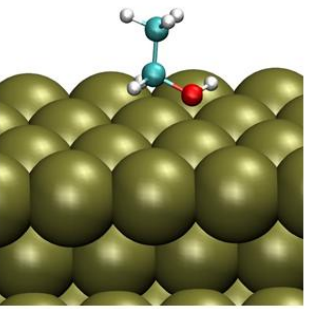

$\Delta E_{\mathrm{ad}}=-\mathbf{0 . 2 6 e V}$

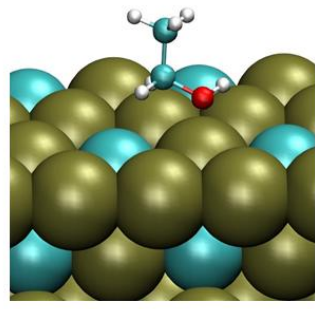

$\Delta E_{\mathrm{ad}}=\mathbf{- 0 . 2 8 \mathrm { eV }}$

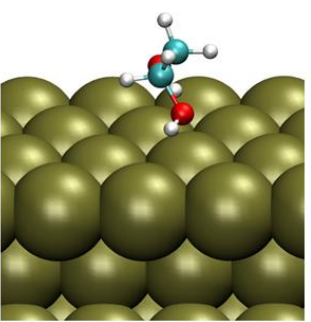

$\Delta E_{\text {ad }}=-\mathbf{0 . 1 8} \mathrm{eV}$

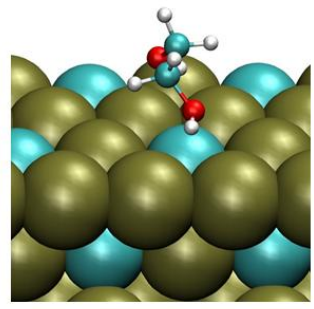

$\Delta E_{\mathrm{ad}}=-0.24 \mathrm{eV}$

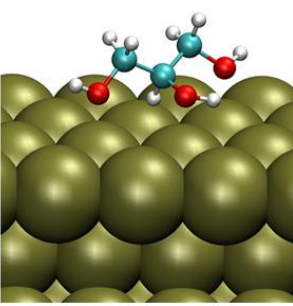

$\Delta E_{\text {ad }}=-0.24 \mathrm{eV}$

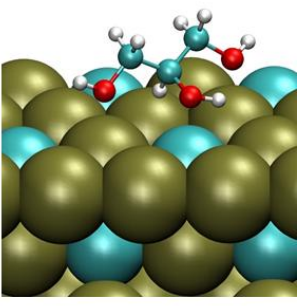

$\Delta E_{\mathrm{ad}}=\mathbf{- 0 . 2 7 \mathrm { eV }}$

Figure 5. Optimized structures of hydroxyl, methanol, ethanol, ethylene glycol, and glycerol adsorbed on $\mathrm{Pd}(111)$ and $\mathrm{Pd}_{3} \mathrm{Cu}(111)$ surfaces as calculated using Density Functional Theory with the Perdew-Burke-Ernzerhof (PBE) functional $[53,54]$ and Vienna Ab initio Software Package (VASP) [55-58].

The adsorption energies of methanol, ethanol, ethylene glycol, and glycerol were calculated as: $-0.22,-0.26,-0.18$ and $-0.24 \mathrm{eV}$ on the $\operatorname{Pd}(111)$ surface and $-0.21,-0.28,-0.24$ and $-0.27 \mathrm{eV}$ on the $\mathrm{Pd}_{3} \mathrm{Cu}(111)$ surface, respectively. Considering entropy losses associated with the adsorption from water solution, the adsorption of any alcohol would be thermodynamically unfavorable as the small change in electronic energy associated with the adsorption will not compensate for the loss of entropy. However, the samples synthesized using the SSM are highly nanostructured. Therefore, due to the confinement of the reactive species in the material pores, entropic losses associated with the adsorption are much smaller, which decreases the adsorption potential of the alcohols. Summing up, the SSM method improves the apparent catalytic activity, not just by increasing the total electrochemically active surface area (as proposed from the electrochemical experiments), but also by decreasing the Gibbs free energy for the adsorption of the considered 
reactants. This effect is especially important for the adsorption of reactants that interact with the catalytic surface by weak dispersion forces, such as interactions of the herein-considered alcohols with $\mathrm{Pd}$ and $\mathrm{Pd}_{3} \mathrm{Cu}$. $\mathrm{OH}$ species chemisorb on the surface of $\mathrm{Pd}$ and $\mathrm{Pd}_{3} \mathrm{Cu}$ and the adsorption energy of $\mathrm{OH}$ groups was calculated as $-2.32 \mathrm{eV}$ on top of $\mathrm{Pd}$ atoms of the $\mathrm{Pd}(111)$ surface, $-2.31 \mathrm{eV}$ on top of $\mathrm{Pd}$ atoms of the $\mathrm{Pd}_{3} \mathrm{Cu}(111)$ surface and $-2.42 \mathrm{eV}$ on top of $\mathrm{Cu}$ atoms of the $\mathrm{Pd}_{3} \mathrm{Cu}(111)$ surface. This results indicates that the surface $\mathrm{Cu}$ atoms are more prone to $\mathrm{OH}$-adsorption than the Pd surface atoms and confirms the assumption of the promotion effect by copper add-atoms on the palladium catalysts discussed above. If we assume that all the other contributions to the Gibbs free energy of adsorption will not differ significantly on these two surfaces, the calculated adsorption energies show that the adsorption potential of $\mathrm{OH}$ on $\mathrm{Pd}_{3} \mathrm{Cu}(111)$ surface shall be $100 \mathrm{mV}$ smaller than on the $\mathrm{Pd}(111)$ surface. The presence of $\mathrm{OH}$ species on the surface of the $\mathrm{Pd}_{3} \mathrm{Cu}$ catalyst at lower cell potentials (at least at the surface $\mathrm{Cu}$ atoms) should be beneficial for the overall mechanisms of alcohol oxidation since those species are involved in various steps of the reactions. Thus, their energetically enhanced adsorption and presence in adequate proportion shall be favorable to the turnover frequency of the catalytic sites. These results can also explain the lower activity of $\mathrm{PdCu}_{3}$ for the alcohols oxidation as compared to $\mathrm{Pd}$ (for ethanol and methanol oxidation reaction), $\mathrm{PdCu}$ and $\mathrm{Pd}_{3} \mathrm{Cu}$. Higher concentrations of $\mathrm{Cu}$ atoms on the catalysts surface will favor large $\mathrm{OH}_{\text {ads }}$ coverage at lower cell potentials, which will decrease the number of metal sites available to adsorb and then electrochemically catalyze (ionize) the alcohols.

Further insights into the reaction mechanisms were obtained by Fourier-transform infra-red (FTIR) spectroscopy. To correlate the spectroscopic and electrochemical results, the electrochemical measurements performed during the acquisition of the FTIR spectra in Figure 6, are presented in Figure S3. The difference between the voltamperograms in Figure S3 and those in Figure 4 can be explained by the difference in the potential sweep rates used in the two cases: 
$v=0.001 \mathrm{~V} \mathrm{~s}^{-1}$ in the quasi-stationary conditions of Figure $\mathrm{S} 3, v s . v=0.020 \mathrm{~V} \mathrm{~s}^{-1}$ in Figure 4. These differences highlight that alcohol and $\mathrm{OH}_{\mathrm{ads}}$ adsorptions are not only limited by thermodynamics but also by kinetics phenomena. The first steps of alcohol oxidation, i.e. the
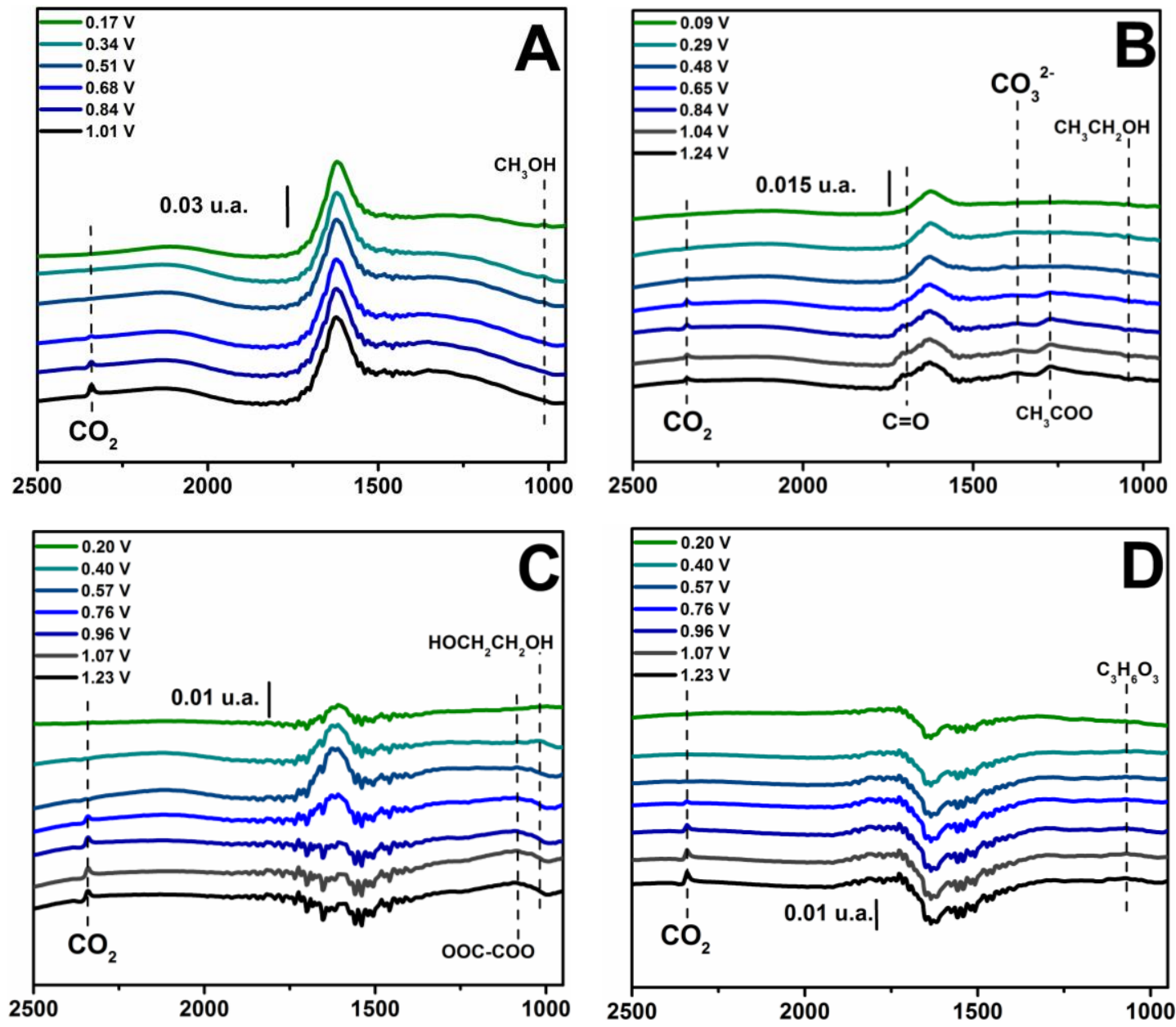

Wavelength $/ \mathrm{cm}^{-1}$

Figure 6. In situ IRRAS spectra of alcohol electrooxidation on $\left.\mathrm{Pd}_{3} \mathrm{Cu}: \mathrm{A}\right) \mathrm{MeOH}, \mathrm{B}$ ) $\mathrm{EtOH}, \mathrm{C}) \mathrm{EG}$ and D) glycerol. Conditions: $0.1 \mathrm{M} \mathrm{KOH}+1 \mathrm{M} \mathrm{MeOH} / \mathrm{EtOH}(0.1 \mathrm{M}$ EG/glycerol), potential values expressed in V vs. RHE.

alcohol adsorption on the catalyst surface occur at $c a . E=0.09-0.4 \mathrm{~V} v s$. RHE, as shown by the appearance of bands at $1010-1070 \mathrm{~cm}^{-1}$, which can be attributed to the various adsorbed alcohols. The oxidation itself occurs at higher potentials, $c a$. $0.6 \mathrm{~V}$ vs. RHE for the EOR, as revealed by the presence of $\mathrm{CO}_{2}$ (total oxidation $-2340 \mathrm{~cm}^{-1}$ ) and acetaldehyde / acetate (partial oxidation $-1700 \mathrm{~cm}^{-1}$ ). It should be noted that acetate species are in solution at higher potentials, i.e. $E=0.65 \mathrm{~V}$ vs. RHE, as shown by the band at $1280 \mathrm{~cm}^{-1}$ [59-64]. The first steps of MOR occur at lower potentials, with total oxidation observed above $E=0.68 \mathrm{~V} v s$. RHE, which is in agreement with the kinetics analysis discussed above. 
According to Simoes [64] and Zalineeva [15], the band at 1070-1100 $\mathrm{cm}^{-1}$ indicates the presence of glyceraldehyde, the formation of which is required to produce the glycerate ion [10]. The appearance of oxalate, an intermediate species involved in the EGOR $[65,66]$, was observed at $0.57 \mathrm{~V}$ vs. RHE. Total oxidation and $\mathrm{C}-\mathrm{C}$ bond cleavage occur on all catalysts, as demonstrated by the $\mathrm{CO}_{2}$ band appearance at $2340 \mathrm{~cm}^{-1}$ at $E=0.60 \mathrm{~V} v s$. RHE for the EOR, GOR and EGOR and $E=0.65 \mathrm{~V}$ vs. RHE for the MOR (Figure 6 and Figure S3). However, partial oxidation still occurs for EOR, as shown by the continued presence of the band at 1280 $\mathrm{cm}^{-1}$, ascribed to "in-solution" acetate (Table 2).

Table 2. Band identification of chemical species by wavenumber and potential of their detection (V vs. RHE) for intermediates of different alcohol oxidized in situ on $\mathrm{Pd}_{\mathrm{x}} \mathrm{Cu}_{\mathrm{y}}$.

\begin{tabular}{|c|c|c|c|}
\hline & Species & Wavelength $\left(\mathrm{cm}^{-1}\right)$ & $\begin{array}{c}\text { Potentials (V vs. } \\
\text { RHE) }\end{array}$ \\
\hline \multirow{2}{*}{ Methanol } & $\mathrm{CO}_{2}$ & 2340 & 0.68 \\
\hline & $\mathrm{CH}_{3} \mathrm{OH}$ & $1000-1020$ & $0.15-0.85$ \\
\hline \multirow{5}{*}{ Ethanol } & $\mathrm{CO}_{2}$ & 2340 & 0.6 \\
\hline & $\begin{array}{c}\mathrm{C}=\mathrm{O} \text { (acetaldehyde, } \\
\text { acetate) }\end{array}$ & 1700 & 0.65 \\
\hline & $\mathrm{CO}_{3}{ }^{2-}$ (in $\mathrm{C}$-H plane) & $1360-1380$ & 0.84 \\
\hline & $\mathrm{CH}_{3} \mathrm{COO}_{\text {sol }}$ & $1270-1280$ & 0.65 \\
\hline & $\mathrm{CH}_{3} \mathrm{COOH}$ & 1040 & $0.09-0.84$ \\
\hline \multirow{3}{*}{ Ethylene Glycol } & $\mathrm{CO}_{2}$ & 2340 & 0.6 \\
\hline & OOC-COO ${ }_{\text {ads }}$ & $1060-1080$ & 0.57 \\
\hline & $\mathrm{HOCH}_{2} \mathrm{CH}_{2} \mathrm{OH}$ & 1020 & $0.2-0.57$ \\
\hline \multirow{2}{*}{ Glycerol } & $\mathrm{CO}_{2}$ & 2340 & 0.6 \\
\hline & $\mathrm{C}_{3} \mathrm{H}_{6} \mathrm{O}_{3}$ & 1070 & 0.4 \\
\hline
\end{tabular}

Chronoamperometry experiments were carried out using the $\operatorname{Pd}_{3} \mathrm{Cu}$ electrocatalyst and different alcohols (Figure 7) to study the catalysts susceptibility toward surface poisoning. This electrocatalyst was selected as one of the best for alcohols electrooxidation reactions, and being the material in which copper-added active sites were associated with FCC PdCu phase only. It 
can be clearly seen that the stability of the experimental curve for the GOR was remarkable. On the other side, all other alcohols exhibit a non-negligible current decrease in the timeframe of the experiment, which is indicative of the catalyst poisoning by intermediate species.

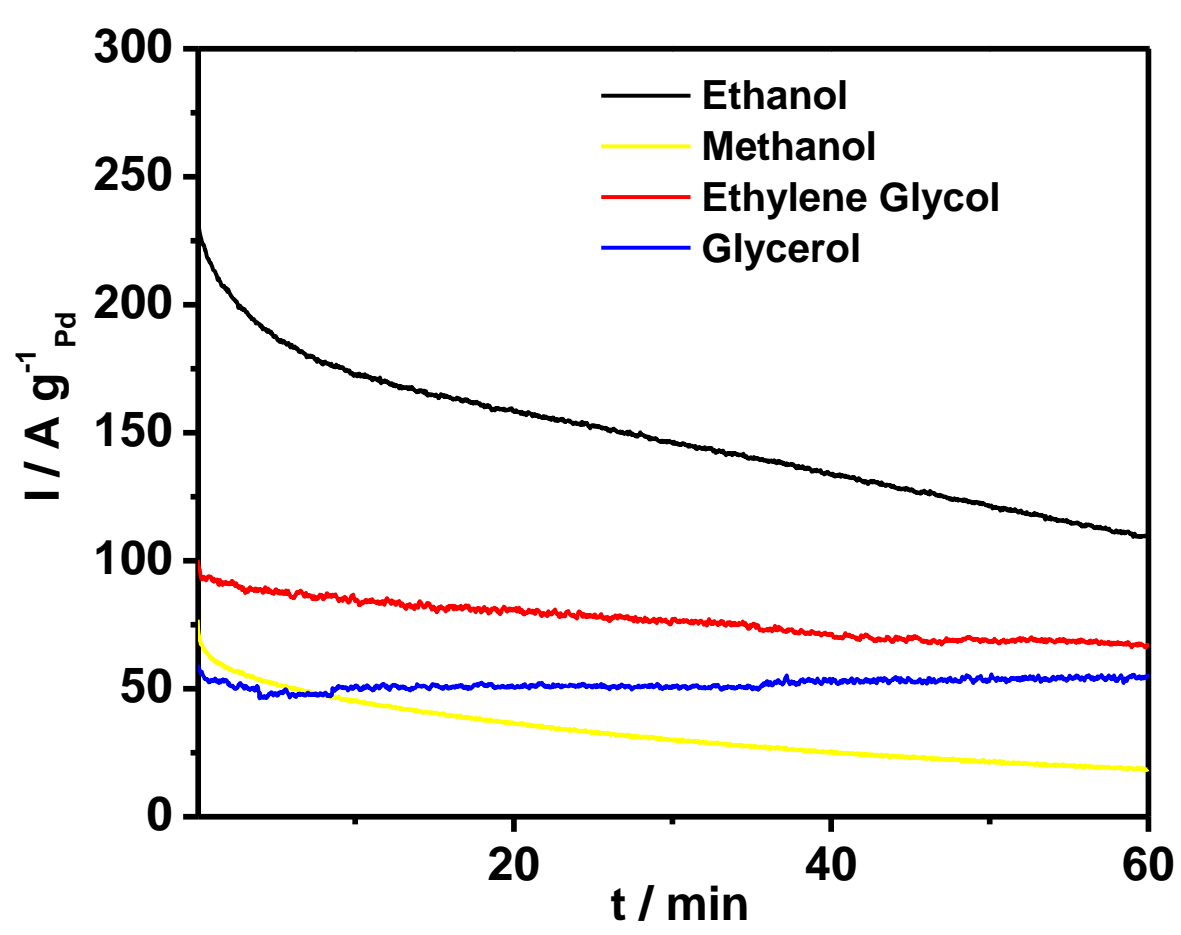

Figure 7. Chronoamperograms plotted to the $\mathrm{Pd}_{3} \mathrm{Cu}$ electrocatalyst at $E=0.7 \mathrm{~V} v s$. RHE for 0.1 $\mathrm{M}$ glycerol, $0.1 \mathrm{M}$ ethylene glycol, $1 \mathrm{M}$ ethanol and $1 \mathrm{M}$ methanol. Conditions: $1 \mathrm{M} \mathrm{KOH}, \mathrm{RT}$, no rotation, $\mathrm{N}_{2}$ purge.

Differential Electrochemical Mass Spectrometry (DEMS) measurements were carried out at the PdCu catalyst with a $1 \mathrm{mM} \mathrm{L}^{-1}$ ethylene glycol as a fuel in $0.1 \mathrm{M} \mathrm{L}^{-1} \mathrm{KOH}$ solution using the experimental procedures described above.

The $\mathrm{CO}_{2}$ current efficiency (CCE, i.e. the proportion of the oxidation current corresponding to the production of $\mathrm{CO}_{2}$, calculated as in Ref. [67]) for the ethylene glycol oxidation at the $\mathrm{PdCu}$ electrocatalyst was quantified by differential electrochemical mass spectrometry (DEMS), based on the calibration of the $\mathrm{m} / \mathrm{z}=22$ and $\mathrm{m} / \mathrm{z}=44$ signals using CO-stripping voltammetry (Figure 
S4). As obtained results were compared to DEMS data measured with Acta ${ }^{\circledR} 3020$ anode catalyst as industrial reference for a supported Pd catalyst. Under potentiostatic conditions, CCE around $40 \%$ were found in the potential range of $0.6<E<0.7 \mathrm{~V} v s$. RHE for the $\quad \mathrm{PdCu}$ electrocatalyst (Figure 8). In comparison, the CCE for the commercial Acta ${ }^{\circledR}$ catalyst in the same potential window stayed below $10 \%$, which demonstrates that $\mathrm{Cu}$ adjunction is not only efficient in promoting larger alcohol oxidation currents, but also enables to direct the EGOR towards a complete pathway. Similar onset potentials for the $\mathrm{PdCu}$ electrocatalysts of about $E=0.6 \mathrm{~V} v s$. RHE were found in the MSCV (Figure S4) and FTIR (Figure S3) spectra. The onset potential in DEMS is identical for both the $m / z=22$ (signature of $\mathrm{CO}_{2}{ }^{++}$, attributed solely to $\mathrm{CO}_{2}$ in the present conditions) and $m / z=44$ (signature of $\mathrm{CO}_{2}^{+}$or of a $\mathrm{C}_{2} \mathrm{H}_{4} \mathrm{O}^{+}$fragment of any aldehydes). As no increase of the $m / z=15$ signal is observed, we can conclude that the $m / z=44$ signal most likely is associated with $\mathrm{CO}_{2}$ evolution. The balance of the faradaic current involved the formation of non-volatile species such as oxalate, that cannot be detected in DEMS but were observed in FTIR, e.g. from the O-C-O bands at $1070-1080 \mathrm{~cm}^{-1}$ (Figure 6 and Table 2). Finally, the lack of $m / z=15$ signal close to the hydrogen evolution region rules out any methane formation, as formerly found for palladium [68] or platinum-based electrocatalyst [69, 70]. 


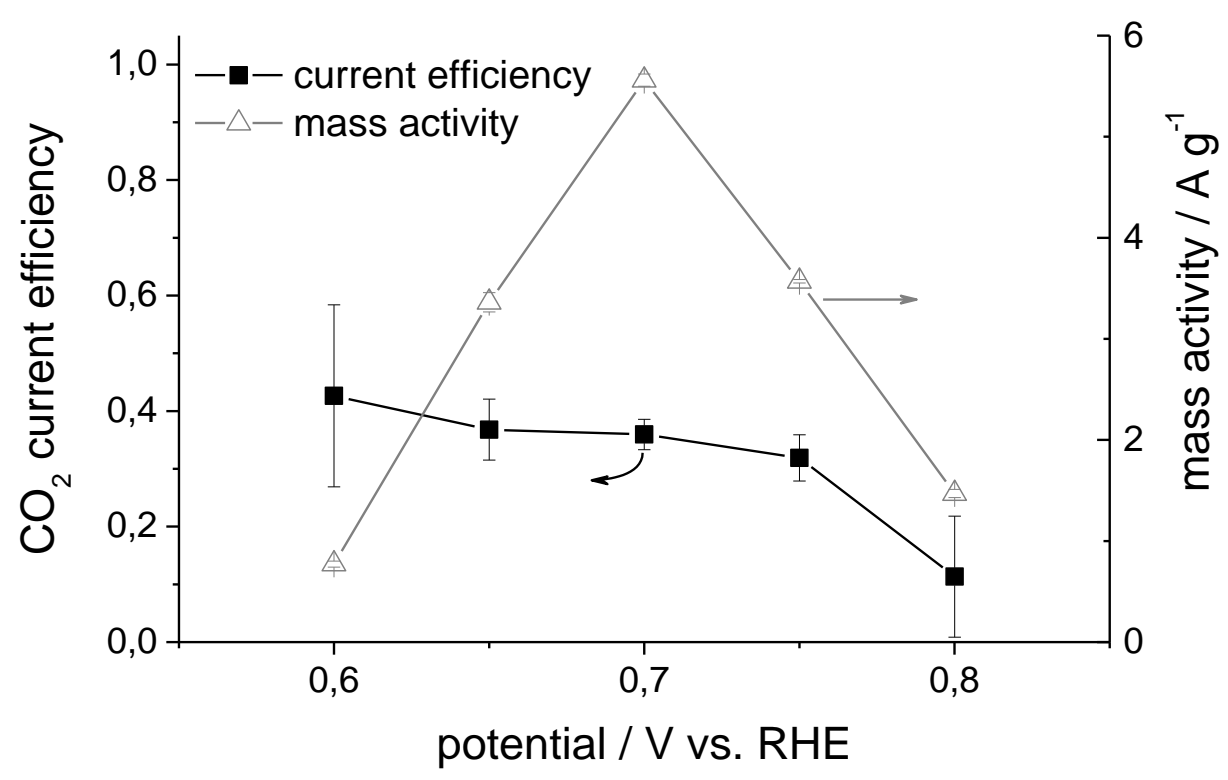

Figure 8. DEMS results for the ethylene glycol oxidation at the $\mathrm{PdCu}$ electrocatalyst in $0.1 \mathrm{M}$ $\mathrm{KOH}$ solution containing $1 \mathrm{mM} \mathrm{EG}$ : CCE under potentiostatic conditions values recorded after $t$ $=20 \mathrm{~min}$.

Based on this study we can conclude that the addition of add-atoms can increase a catalytic activity of palladium for electrooxidation of oxygenated fuels. Several crucial points have to be considered when designing a new palladium based material: i) second element should be hydrophilic; ii) second element or its compounds should not interfere with electronic conductivity of final material; iii) in the case of easy susceptibility to oxidation, the oxide phase of add-atoms should work as a co-catalyst and should not prevent the access of fuel to active sites and removal the products from the active sites; and iv) add-atom should affect the mechanism of fuel oxidation (to $\mathrm{CO}_{2}$ if the final goal is creation of fuel cell device or to Value Added Products if the goal is to make an electrochemical reactors), and vi) detailed mechanism should be evaluated by in situ experimental methods (DEMS, FTIR etc). 


\section{Conclusions}

A series of $\mathrm{Pd}_{\mathrm{x}} \mathrm{Cu}_{\mathrm{y}}$ electrocatalysts was synthesized by the modified SSM and characterized by SEM, TEM, BET and XRD. It was found that the SSM enables preparation of highly dispersed non-supported materials with high surface area. TEM micrographs and XRD diagrams revealed that the electrocatalysts nanoparticles were finely dispersed into small crystallites organized in larger agglomerates, with no significant coalescence within the agglomerates, except for the $\mathrm{PdCu}_{3}$ samples. The presence of copper in adjunction of palladium promotes methanol, ethanol, ethylene glycol and glycerol electrooxidation, especially in the cases of the $\mathrm{PdCu}$ and $\mathrm{Pd}_{3} \mathrm{Cu}$ electrocatalysts, resulting in decreased onset potentials and larger oxidation currents. This positive effect was related to the presence of surface copper sites, which favor $\mathrm{OH}_{\text {ads }}$ species adsorption, which was confirmed by the use of DFT calculations. An unusual increase of the activity in the electrooxidation of ethylene glycol was also observed for $\mathrm{PdCu}_{3}$ catalyst, which can be attributed to the presence of metallic copper and $\mathrm{Cu}_{2} \mathrm{O}$. The decreased palladium content is an attractive economic feature for industrial applications of these catalysts. Based on the results of in situ FTIR experiments the $\mathrm{C}-\mathrm{C}$ bond cleavage was demonstrated for all the $\mathrm{Pd}_{\mathrm{x}} \mathrm{Cu}_{\mathrm{y}}$ electrocatalysts. Based on the observed results and their analysis we suggested strategies for the rational design of $\mathrm{Pd}-\mathrm{X}$ materials. We believe that after their further optimization, all studied Pd-Cu electrocatalysts may be used in combined reactors for electricity and value-added products manufacturing. 


\section{Acknowledgements}

M. C. thanks the Institut Universitaire de France (IUF) for its support. P. A. and M. C. thank Région Rhône-Alpes and Grenoble-INP for the mobility grants they allocated (CMIRA Accueil PRO 2014). Computational work was performed using the computational resources of LANL, supported by the Office of Science of the U.S. Department of Energy under Contract No. DEAC52-06NA25396 and EMSL, a national scientific user facility sponsored by the Department of Energy's Office of Biological and Environmental Research and located at Pacific Northwest

National Laboratory This paper has been designated LA-UR 14-26546. C.C. and D.B. thank the German Federal Ministry of Defense for the financial support in parts of their work.

\section{References :}

[1] Vielstich, W.; Lamm, A.; Gasteiger, H.A. Handbook of Fuel Cells, Wiley, Chichester, 2003.

[2] Gasteiger, H.A.; Vielstich, W.; Yokokawa, H. Handbook of Fuel Cells, John Wiley \& Sons Ltd, Chichester, 2009.

[3] Wasmus, S.; Kuver, A. J. Electroanal. Chem., 1999, 461, 14.

[4] Antolini, E.; Energy Environ. Sci. 2009, 2, 915-931.

[5] Serov, A.; Nedoseykina, T.; Shvachko, O.; Kwak, C. J. Power Sources, 2010, 195, $175-$ 180.

[6] Serov, A.; Kwak, C.; Catal. Comm., 2009, 10 1551-1554. 
[7] Song, S.; Tsiakaras, P. Appl. Catal. B. 2006, 63, 187-193.

[8] Serov, A.; Kwak, C. Appl. Catal. B. 2010, 97, 1-12.

[9] Yu, X.; Pickup, P. G. J. Power Sources. 2008, 182, 124-132.

[10] Serov, A.; Kwak, C. Appl. Catal. B. 2010, 98, 1-9.

[11] Serov, A.; Kwak, C. Appl. Catal. B. 2009, 91, 1-10.

[12] Demirci, U. B.; Miele, P. Energy Environ. Sci. 2009, 2, 627-637.

[13] Tylus, U.; Jia, Q.; Strickland, K.; Ramaswamy, N.; Serov, A.; Atanassov, P.; Mukerjee, S. J. Phys. Chem. C, 2014, 118, 8999-9008.

[14] Serov, A.; Artyushkova, K.; Atanassov, P. Adv. Energy Materials. 2014 DOI: 10.1002/aenm.201301735.

[15] Zalineeva, A.; Serov, A.; Padilla, M.; Martinez, U.; Artyushkova, K.; Baranton, S.; Coutanceau, C.; Atanassov, P. J. Am. Chem. Soc. 2014, 136, 3937-3945.

[16] Serov, A.; Tylus, U.; Artyushkova, K.; Mukerjee, S.; Atanassov, P. Appl. Catal. B: Environ. 2014, 150, 179-186.

[17] Serov, A.; Aziznia, A.; Benhangi, P. H.; Artyushkova, K.; Atanassov, P.; Gyenge, E. J. Mater. Chem. A. 2013, 1, 14384-14391.

[18] Serov, A.; Martinez, U.; Atanassov, P. Electrochem. Commun. 2013, 34, 185-188.

[19] Serov, A.; Robson, M. H.; Smolnik, M.; Atanassov, P. Electrochim. Acta. 2013, 109, 433-439. 
[20] Robson, M. H.; Serov, A.; Artyushkova, K.; Atanassov, P. Electrochim. Acta. 2013, 90, 656-665.

[21] Brocato, S.; Serov, A.; Atanassov, P. Electrochim. Acta. 2013, 87, 361-365.

[22] Serov, A.; Robson, M. H.; Artyushkova, K.; Atanassov, P. Appl. Catal. B. 2012, 127, 300306.

[23] Serov, A.; Robson, M. H.; Smolnik, M.; Atanassov, P. Electrochim. Acta. 2012, 80, 213 218.

[24] Serov, A.; Martinez, U.; Falase, A.; Atanassov, P. Electrochem. Commun. 2012, 22, $193-$ 196.

[25] Serov, A.; Robson, M. H.; Halevi, B.; Artyushkova, K.; Atanassov, P. Electrochem. Commun. 2012, 22, 53-56.

[26] Falase, A.; Main, M.; Garcia, K.; Serov, A.; Lau, C.; Atanassov, P. Electrochim. Acta. 2011, 66, 295-301.

[27] Konopka, D.A.; Li, M.; Artyushkova, K.; Marinkovic, N.; Sasaki, K.;

Adzic, R.; Ward, T. L.; Atanassov, P. J. Phys. Chem. C. 2011, 115, 3043-3056.

[28] Faguy, P.W.; Marinkovic, N.S. Appl Spectrosc. 1996, 50, 394-400.

[29] Hu, S.; Scudiero, L.; Ha, S. Electrochimica Acta, 2012, 83, 354-358.

[30] Hamm, U.W. et al. Electrochimica Acta., 1998, 43, 2969-2978.

[31] Parsons, R.; VanderNoot, T. J. of Electroanalytical Chemistry, 1988, 257, 9-45. 
[32] Ines, F.; Jiang, L.-C.; Derek, P. J. of The Electrochemical Society, 1983, 130, 2187-2192.

[33] Xia, X.H.; Iwasita, T. J. of The Electrochemical Society, 1993, 140, 2559-2565.

[34] Watanabe, M.; Horiuchi, M.; Motoo, S. J. of Electroanalytical Chemistry, 1988, 250, $117-125$.

[35] Adzic, R.R.; et al. J. of Electroanalytical Chemistry, 1977, 80, 81-99.

[36] Adzic, R.R.; et al., J. of Electroanalytical Chemistry, 1975, 65, 587-601 (2, Part 2).

[37] Bianchini, C.; Shen, P.K. Chemical Reviews, 2009, 109, 4183-4206.

[38] Marchionni, A.; et al. ChemSusChem 2013, 6, 518-528.

[39] Motoo, S.; Watanabe, M. J. of Electroanalytical Chemistry, 1976, 69, 429-431.

[40] Watanabe, M.; Motoo, S. J. of Electroanalytical Chemistry, 1975, 60, 259-266.

[41] Modibedi, R.M.; Masombuka, T. ; Mathe, M.K. International Journal of Hydrogen Energy 2011, 36, 4664-4672.

[42] Du, W.; Mackenzie, K.E.; Milano, D.F.; Deskins, N.A.; Su, D.; Teng, X. ACS Catalysis, 2012, 2, 287-297.

[43] Switzer, E.E.; Olson, T.S.; Datye, A.K.; Atanassov, P.; Hibbs, M.R.; Cornelius, C.J. Electrochimica Acta, 2009, 54, 989-995.

[44] Zhang, Z.; Xin, L.; Sun, K.; Li, W. International Journal of Hydrogen Energy, 2011, 36 12686-12697.

[45] Maiyalagan, T.; Scott, K. Journal of Power Sources, 2010, 195, 5246-5251. 
[46] Sadiki, A.; Vo, P.; Hu, S.; Copenhaver, T. S.; Scudiero, L.; Ha, S.; Haan, J L. Electrochimica Acta, 2014, 139, 302-307.

[47] Xu, W.; Zhu, S.; Li, Z.; Cui, Z.; Yang, X. Journal of Power Sources, 2015, 274 10341042.

[48] C. Xu, Z. Tian, P. Shen, S.P. Jiang, Electrochimica Acta, 2008, 53, 2610-2618.

[49] Zhang, L.; Li, H.; Ni, Y.; Li, J.; Liao, K.; Zhao, G. Electrochemistry Communications, 2009, 11, 812-815.

[50] Dong, S.; Zhang, S.; Cheng, X.; He, P.; Wang, Q.; Fang, Y. Journal of Chromatography $A, \mathbf{2 0 0 7}, 1161,327-333$.

[51] Zhang, Y.; Liu, Y.; Su, L.; Zhang, Z.; Huo, D.; Hou, C.; Lei, Y. Sensors and Actuators B: Chemical, 2014, 191, 86-93.

[52] Amin, R.S.; Abdel Hameed, R.M.; El-Khatib, K.M.; El-Abd, H.; Souaya, E. R. International Journal of Hydrogen Energy, 2012, 37, 18870-18881.

[53] Perdew, J. P.; Burke K.; Ernzerhof, M. Phys. Rev. Lett. 1996, 77, 3865.

[54] Perdew, J. P.; Burke K.; Ernzerhof, M. Phys. Rev. Lett. 1997, 78, 1396.

[55] Kresse G.; Hafner, J. Phys. Rev. B. 1993, 47, 558.

[56] Kresse G.; Hafner, J. Phys. Rev. B. 1994, 49, 14251.

[57] Kresse G.; Furthmüller, J. Comput. Mat. Sci. 1996, 6, 15.

[58] Kresse G.; Furthmüller, J. Phys. Rev. B. 1996, 54, 11169. 
[59] Shao, M.H.; Adzic, R.R. Electrochim. Acta. 2005, 50, 2415.

[60] Lima, F. H. B.; Gonzalez, E. R. Electrochim. Acta. 2009, 53, 2963.

[61] Kowal, A.; Li, M.; Shao, M.; Sasaki, K.; Vukmirovic, M. B.; Zhang, J.; Marinkovic, N. S.; Liu, P.; Frenkel, A. I.; Adzic, R. R. N Materials, 2009, 2359.

[62] Li, M.; Kowal, A.; Sasaki, K.; Marinkovic, N.; Su, D.; Korach, E.; Liu, P.; Adzic, R. R.; Electrochim. Acta. 2010, 55, 4331.

[63] Li, M.; Zhou, W.-P.; Marinkovic, N. S.; Sasaki, K.; Adzic, R. R. Electrochim. Acta. 2013, $104,454$.

[64] Simoes, M.; Baranton, S.; Coutanceau, C. Appl. Catalysis B: Environ. 2010, 93, 354.

[65] Xin, L.; Zhang, Z.; Qi, J.; Chadderdon, D.; Li W. Appl. Catalysis B: Environ. 2012, 125, 85.

[66] Wang, L.; Meng, H.; Shen, P. K.; Bianchini, C.; Vizza, F.; Wei, Z. Phys. Chem. Chem. Phys. 2011, 12, 2667.

[67] Delpeuch, A.B.; Asset, T.; Chatenet, M.; Cremers, C.; J. Electrochem. Soc., 2014, 161, F918.

[68] Cantane, D.A.; Lima, F.H.B.; Electrocatal., 2012, 3. 324.

[69] Bach Delpeuch, A.; Chatenet, M.; Cremers, C.; Tübke, T.; Electrochim. Acta, 2014, 141, 102.

[70] Bayer, D.; Cremers, C.; Baltruschat, H.; Tübke, J.; ECS Transactions 2011, 41(1), 1669 
Graphical Abstract

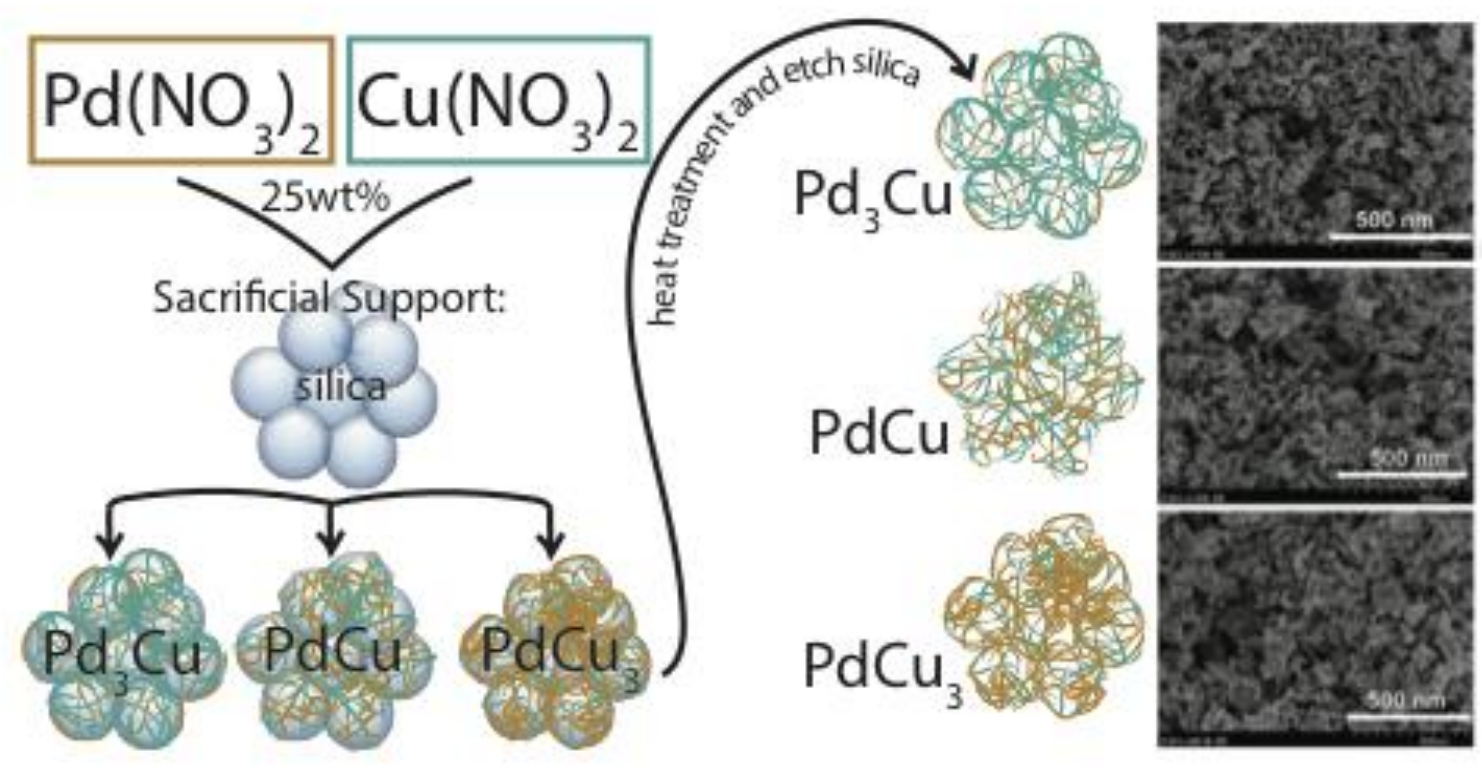

A sacrificial support method (SSM) in combination with thermal reduction of metal precursors was used for the preparation of palladium-copper catalysts. The materials with $\mathrm{Pd}: \mathrm{Cu}$ ratios of 1:3, 1:1 and 3:1 were synthesized and characterized via XRD, SEM, TEM, XPS, DEMS and BET techniques. The catalytic activity for the electrooxidation of methanol, ethanol, ethylene glycol and glycerol was investigated in alkaline media. 